\title{
INTRODUCTION
}

1. For 2014. As compared to iron ore (1,610 million tonnes in 2013), gold (3,923 tonnes in 2014), or potash (56 million tonnes), for example (Basson 2014; PotashCorp 2014; George 2016).

2. Whether the events of 2010 constituted a "crisis" is a matter of considerable debate. The "crisis," real or not, has become parlance for the price increases and attendant geopolitical and economic uncertainty that followed. That the crisis was not what many thought it to be, that China's central government maintained plausible deniability throughout, and that commodity flows may have been only minimally disrupted will be thoroughly examined in chapter 4 and therefore are not points that need to be belabored by using "crisis" in quotation marks hereafter.

3. According to the USGS: "A mineral deposit is a mineral occurrence of sufficient size and grade that might, under the most favorable circumstances, be considered to have economic potential (Cox 1986). Deposits sharing a relatively wide variety and large number of attributes are characterized as a 'type,' and a model representing that type can be developed" (quoted in Berger, Singer, and Orris 2009, 2).

4. Fortunately, the discourse is much more careful and nuanced in academic journals and edited volumes. For example, see Wübbeke 2013 for an analysis of China's rare earth policy narratives. The collection edited by Ryan David Kiggins (2015), titled The Political Economy of Rare Earths: Rising Powers and Technological Change, is the first compilation of social science analyses of the contemporary rare earth issue. The chapters in this volume decisively refute the hypothesis that dependence on China constitutes an existential threat to the United States or other countries dependent on China's rare earths.

5. Geographers tend to understand these human-environment relations as taking on three spatial forms: real, perceived, and lived. Real space refers to physical space, as in the land and environment, and their physical properties. Perceived space refers to people's ideas, cultural norms, and abstractions about space, as in ideas that consider some places more important, dangerous, or strategic than others, for any reason. Lived space refers to the actual practice of people and institutions carrying out their daily activities shaped by their physical environments and their ideas about their environments. In practice, lived space combines real and perceived space to produce the world as we know and experience it (Lefebvre 1991).

6. Such inducements are known as a pro-rata nonrenounceable entitlement offer.

7. For a discussion of how artisanal mining practices differ and interact with statebacked large-scale commercial mining enterprises, see Hecht and Cockburn 1990; Hinton, Viega, and Beinhoff 2003; and Lahiri-Dutt and MacIntyre 2011.

8. Senior vice president for investor relations of an anonymous rare earth mining and processing firm, interview by author, June 2014.

9. As discussed in chapter 4, illegal rare earth production and export in China is estimated to exceed official exports by up to 40 percent.

10. See, e.g., Fulp 2012.

11. This has important similarities with obstacles to deep seabed extraction, although deep seabed extraction is demonstrably more feasible than lunar mining. 
12. Transportation costs are likewise a barrier to production in São Gabriel da Cachoeira.

13. "If you're going to have a Sputnik moment, how about mining an asteroid for natural resources? ... There's more natural resources on asteroids than have ever been mined in the history of the earth. So I would say we have to turn space into our backyard" (Tyson 2015).

14. Many of whom came into this wealth by developing and innovating rare earthdependent technologies.

15. $\mathrm{K}=$ potassium, $\mathrm{REE}=$ rare earth elements, and $\mathrm{P}=$ phosphorus.

16. Further incentivized by career pressures for local officials to increase the local GDP.

17. Closing statements at military geology forum, Manaus, April 26, 2014.

18. China Academy of Sciences delegation to Brazil, interview by author, March 2013.

19. China Academy of Sciences research faculty, interview by author, August 2013.

20. See, e.g., Grasso 2013; Information Office 2012.

21. As discussed in chapters 4 and 5.

22. Such approaches characterize the positivist, Eurocentric approach and all of its pitfalls, which have been roundly and rightly critiqued as a misguided way to study histories of development (McMichael 1990).

\section{WHAT ARE RARE EARTH ELEMENTS?}

1. At the time, metallic oxides were referred to as earths. For example, magnesia was known as "bitter earths," zirconia as "zirconium earths," and beryllia as "beryllium earths" (Greinacher 1981).

2. "Until 1885, though by that time the scientific interest of the group had been fully demonstrated by the discovery of several new elements, it was supposed that the minerals were almost entirely confined to a few scattered localities in Scandinavia and the Ural mountains. In that year Dr. Auer von Welsbach announced his application of the rare earths to the manufacture of incandescent mantles. Immediately there was a great demand for raw material for the preparation of thoria and ceria. The agents of the Welsbach Company visited all the important mining centers of Europe and America, intent on a search which shortly made it clear that the metals of so-called 'rare earths' are really quite widely distributed in nature" (Levy 1915, 2).

3. Promethium is occasionally excluded from the rare earth group because it is a synthetic radioactive element produced during nuclear fission and is found, on Earth, only in spent nuclear fuel. It is also found in the center of certain stars in the Andromeda galaxy (Cardarelli 2008; Jørgensen 1990).

4. Periodized by Greinacher (1981) as lasting from 1891, when Auer von Welsbach was awarded his patent, to 1930, when the properties of rare earth elements began to be used more widely, but before the launch of various atomic research programs during which the properties of rare earth elements were more systematically discovered.

5. The other 99 percent was thorium.

6. "The development of new uses for the rare earths has been discouraged because the supply has been considered limited and the price, even of foreign ore, has been unstable" (Congress 1952, 23).

7. Pyrophoric: liable to ignite spontaneously upon exposure to air. Google analytics show that use of the word peaked mid-twentieth century, suggesting that Evans et al. (2002) were not alone in watching their lab equipment go up in smoke.

8. Or 800 pounds of neodymium and 130 pounds of dysprosium.

9. Or two tons.

10. MRI machines use over 680 kilograms of magnets each (Molycorp 2012). 
11. A few efforts to catalog rare earth applications; environmental, social, and economic impacts; and sites of extraction, enclosure, and pollution are under way. Most notable among these is The Rare Earth Catalog: Tools for Reckoning with the Anthropocene currently being organized by Elizabeth Knafo and Jesse Goldstein.

12. "When thorium 232 captures a slow neutron, it converts to thorium 233. The thorium then disintegrates quickly into protactinium 233 , which then decomposes, but more slowly, into uranium 233. Uranium 233 is fissionable by slow neutrons and thus potentially a material for sustaining a chain reaction. Thorium, like uranium, occurs widely in the earth's crust, but similarly not often in sufficient concentration to provide economically workable deposits. Before World War II, it was most commonly used in the manufacture of gas mantles" (Jones 1985, 292n1).

13. Brazil-Germany relations during the 1930s suggested that Brazil would support Germany in the event of war. President/dictator Getulio Vargas (1930-45, 1951-54) reportedly enjoyed Adolf Hitler's company and was sympathetic to Nazism/fascism in the 1930s. Germany was Brazil's second largest trading partner until 1940 (Penteado 2006).

14. That is, capturing and enslaving local inhabitants (Helmreich 2014). Headrick (1978), Dumett (1985), Israel (1987), Von Eschen (1997), and Harrison (1998), inter alia, demonstrate how winning the war and the nuclear arms race depended on the exploitation of the colonized world, although the lives lost through forced labor regimes are seldom included in tallies of World War II casualties.

15. These records, based on US military archives, do not cohere with the findings reported by Adam Hochschild (1999) in King Leopold's Ghost: A Story of Greed, Terror, and Heroism in Colonial Africa: "With the start of the Second World War, the legal maximum for forced labor in the Congo was increased to 120 days per man per year. More than 80 percent of the uranium in the Hiroshima and Nagasaki bombs came from the heavily guarded Congo mine of Shinkolobwe" (279).

16. "After World War II, owing to the recovery of lanthanide elements in fission products during the reprocessing of spent nuclear waste, the separation of rare earths was greatly improved, and this led to the large commercial-scale solvent-extraction process now widely used to recover lanthanides for industrial applications" (Cardarelli 2008, 423).

17. The chemical and conceptual symbiosis drove advances in rare earth and nuclear research on opposite sides of the globe through the mid-twentieth century. Frank Spedding's discovery of ion exchange for rare earth separation proved crucial to isolating uranium in the 1940s. Xu Guangxian's work on isolating uranium was critical for his discovery of the cascade theory of countercurrent extraction, which revolutionized rare earth production and greatly increased the global rare earth supply in the 1970s.

18. The environmental and epidemiological effects are examined in-depth in chapter 3 , with a detailed analysis of Baotou, Bayan Obo, and vicinity.

19. "We have got to take control of our energy future and we can't let that energy industry take root in some other country because they were allowed to break the rules" (Obama quoted in Chapple 2012).

20. Chairman of the Ministry of Land and Resources for Baotou Municipality, interview by author, September 2013.

21. Representative of International Economic Engagement of the Ministry of Foreign Affairs of the People's Republic of China, interview by author, September 2013.

22. Mr. Chen (Chinese Society of Rare Earths), interview by author, September 2013.

23. For a discussion of this dynamic in US, Japanese, and Chinese literatures, see Bruce, Hietbrink, and DuBois 1963; Hirano and Suzuki 1996; and Li, Yang, and Jiang 2012, respectively. 
24. A minable concentration is generally defined as a percentage "in the low singledigits"; a spatially defined area of concentrated minerals is called an "occurrence." If it is minable, then it is called a "deposit," "ore deposit," or "mineral deposit" (Zepf 2013).

25 . On the black market, elements are immersed in crude acid baths to partially separate them and are then sold to downstream refining facilities via independent traders (Bradsher 2010). This, in part, explains why there is such an extensive delay between discovery and production, and why production is so environmentally devastating.

26. For the sake of simplicity, I am talking about the formation of a bastnäsite IronREE-Th deposit here, such as those found in Bayan Obo, Seis Lagos, and Mountain Pass.

27. The field of lunar geology is called selenology.

28. KREEP: $\mathrm{K}=$ Potassium, $\mathrm{REE}=$ Rare Earth Elements, and $\mathrm{P}=$ Phosphorus.

29. Foweraker (1981) has observed that "marginal" and "frontier" tend to overlap.

30. This is meant in the Gramscian sense in that "the moment of hegemony" is revealed when the dominant bloc "also pos[es] the questions around which the struggle rages" (Gramsci, Hoare, and Nowell-Smith 1971, 182 quoted in Goldman 2005, 7).

\section{PLACING CHINA IN THE WORLD HISTORY OF DISCOVERY, PRODUCTION, AND USE}

1. "Self-sufficiency is a very Chinese term. The US committed to an efficient, global system of free trade in order to keep prices low for American companies" (United States government representative, executive branch, interview by author January 2014).

2. In Baotou and Bayan Obo, the legacies of these efforts are present in the rather surprising abundance of protestant churches (Liu 2009). These churches survived the purges of foreign influence in the early years of the PRC by aligning themselves with nationalist campaigns. They were particularly active in the "Three Self-Sufficiencies Patriotic Campaign" of the late 1950s and early 1960s, which consisted of "Self-Governance, SelfTeaching, and Self-Support" (Wang 2010, 15).

3. Reports from the first year of meetings recount several instances of Japanese, American, Russian, and Chinese researchers literally opening their field notebooks for one another (Liu 2009).

4. Also referred to as the Nationalists or the Republicans.

5. A euphemism for purging communists and other "undesirables," which culminated in the Shanghai Massacre of 1927. See Stranahan 1998 and Wakeman 1995, inter alia.

6. This was significant: it included tons of ammonium nitrate (for explosives), heavy artillery, airplanes, and submarines.

7. The production of both of these elements is currently concentrated in China. As of 2013 , China produced 80 percent of the global supply of antimony, and was aggressively buying up (and then closing) foreign firms. China currently produces about 85 percent of the global supply of Tungsten (Bromby 2013) while global shortages in the early 2000s have driven the United States and Russia to sell off domestic stockpiles. Both of these elements, like rare earths, are considered critical materials. The fixation on rare earth elements has perhaps hindered a more holistic approach to strategic questions concerning the geography of critical materials production and consumption.

8. Also Romanized as Ho Tzao-lin.

9. Also known in the Sinicized form as Teh Wang.

10. Also Romanized as General Fu Tso-yi.

11. Called Mongokuo, modeled on Japanese advice after Manchukuo in northeastern China. Japan claimed that their imperial forces had nothing to do with this, even stating that the land was "too barren" for them to be interested in incorporating it. This conflicts with reports from missionaries at the time, which corroborated Chinese reports that Mongolian forces were under Japanese command. 
12. "The reports said the new nation carved out of northern Chahar province included and area roughly the size of the state of Ohio. Bounded on the north by outer Mongolia, one the east by Jehol province, and on the west by the strongly fortified Chinese province of Suiyuan, its southern border was said to have been placed along the Great Wall, extending at one point with 20 miles north of Kalgan" (Gandhi, Mu, and Honrath 2013).

13. In his remarks on March 5, 1949, Mao emphasized the Suiyuan style of revolutionary victory "as a bloodless method of struggle, but that is not to say it isn't struggle ... that captures a portion of the Nationalist army and strives for them to stand up on our side of politics" (Bai 1999, i).

14. Also known as the Yalta Agreement.

15. This despite the fact that Article 5 of the previous treaty, the "Agreement on General Principles for the Settlement of Questions between the Republic of China and the USSR" signed on May 31, 1924, contained the following language: "The Government of the USSR recognizes that Outer Mongolia is an integral part of the Republic of China and respects China's sovereignty therein" (Republic of China and USSR 1924). In December 1924, Georgy Chicherin, the commissar for foreign affairs of the USSR, issued the following statement, which was taken to define the "status quo" as used in the Yalta Agreements: "We recognize the Mongolia People's Republic as part of the Chinese Republic, but we recognize also its autonomy in so far-reaching a sense that we regard it not only as independent of China in its internal affairs, but also as capable of pursuing its foreign policy independently" (Associated Press 1937a).

16. In northwestern China as in northwestern Brazil these histories have been extensively studied. See, for example, Figueireido 1967; Bulag 2002; and Tyner 2012.

17. See, e.g., Hsü 1982.

18. These are the Pinceance and Uinta Basins in the United States; the Orinoco Belt in Venezuela, and the Alberta Oil Sands in Canada.

19. IMAR People's Standing Committee Ethnic Affairs Representative, interview by author, April 2013.

20. Or politics and economy, or policy and markets, or power and technology (Clausewitz 1976; Guo 2013; Lauren, Craig, and George 2007). Rich literatures are devoted to defining these couplets and the relationship within them. "War and industry" is decidedly more antiquated than the others; I use it deliberately in order to capture the particular form of the political and economic imperatives that sought to render the southern Mongolian Steppe into a red hinterland for the People's Republic of China and the Soviet Union (Hurst 2010; Jia and Di 2009). For an excellent discussion of the relationship between war and the state, see Treatise on Nomadology — The War Machine (Deleuze and Guattari 1987).

21. "There is more to the picture than semiotic systems waging war on one another armed only with their own weapons. Very specific assemblages of power impose significance and subjectification as their determinate form of expression, in reciprocal presupposition with new contents: there is no significance without despotic assemblage, no subjectification without an authoritarian assemblage, and no mixture between the two without assemblages of power that act through signifiers and act upon souls and subjects. It is these assemblages, these despotic or authoritarian formations, that give the new semiotic system the means of its imperialism, in other words, the means both to crush the other semiotics and protect itself against any threat from the outside" (Deleuze and Guattari 1987, 418-420; emphasis added).

22. These campaigns have been studied and well documented elsewhere (Chan, Madsen, and Unger 1992; Eberstadt 1980; Hinton 1966; Lin 2990; Pye 1999; Schwartz 1968; Shapiro 2001; Terrill 1999).

23. In Bulletin 16 of the Cold War International History Project, Zhou Enlai reportedly explained to Anastas Mikoyan in February 1949: "We do not have contacts with the 
Xinjiang democratic groups. Our former people there were arrested by [one time governor of Xinjiang] Sheng Shicai. Now we are sending a small group of comrades there." As quoted in the "Memorandum of Conversation between Anastas Mikoyan and Zhou Enlai, February 1, 1949 (Evening)" (quoted in Kraus 2010 7n.).

24. Composed of the intelligence organizations of the US Departments of State, the Army, the Navy, the Air Force, and the Joint Chiefs of Staff.

25. See, for example, Xu 1996, 1998; Shih 1998; and Brook and Luong 1999.

26. For further discussion of this, see Bulag 2002 and Klinger 2017a.

27. However, it was not until 2014 that women were deployed to the front lines of national security in Inner Mongolia (Zou 2014).

28. In the popular imagination, women from these places are thought to be exceptionally beautiful.

29. Mr. Li (PLA veteran on the northwestern front), interview by author, April 2013.

30. Representatives of Baotou Municipal Women's Committee, interviews by author, April 2013.

31. Prerevolution name for Baotou, assigned during the Qing dynasty. See Tighe 2005 for an excellent history.

32. Representative of Baotou municipal family planning bureau, interview by author, April 2013.

33. The large circular tents are typical of Mongolian nomads and celebrated as symbols of life, home, and wellness. Natural features that resemble yurts are attributed sacred status in Mongolian spirituality.

34. Traditional Mongolian medicine practitioner in Bayan Obo, interview by author, September 2013.

35. Communist Party youth volunteer Ms. Hu, escorted survey and interviews in Bayan Obo and vicinity, September 2013.

36. Best among the exceptions are Wu 1965; Clark 1973; and Hogan 1999.

37. "During the period 1950-1954 the Chinese Communists, with some Soviet aid, explored a number of areas for uranium resources. In 1955 this quest for uranium, as well as the supporting Soviet aid, was intensified" (Joint Atomic Energy Intelligence Committee 1960,2$)$.

38. See, e.g., Li et al. 1987.

39. See, for example, Di 1976 and Joint Atomic Energy Intelligence Committee 1960.

40. This is the basis of the solvent extraction methods used today, which utilize the slight variations in the solubility of rare earth compounds between two liquids that do not dissolve into each other (the same principle as oil and water). Countercurrent cascades carry out many extraction steps in a continuous stream that progressively increases the degree of separation until the substance approaches purity (Gray 2009).

\section{3. “WELCOME TO THE HOMETOWN OF RARE EARTHS"}

1. The terms globalization and global capitalism are often used interchangeably. This is due to the hegemony of neoliberal ideologies and practices that are understood to be behind both processes.

2. Heterogeneous economic spaces are not peculiar to China, but rather are also found in other "epicenters" of neoliberalism. See, for example, White and Williams 2012.

3. The messiness of the state's involvement in the rare earth sector in the United States, Brazil, and China is a case in point.

4. As Foucault puts it: "The market ... can only appear if it is produced, and if it is produced by an active governmentality. There will thus be a sort of complete superimposition of market mechanisms, indexed to competition, and governmental policy. Government must accompany the market economy, from start to finish" (2010, 121; emphasis added). 
5. For an important exception to this analysis, particularly as it pertains to the post2008 US context, see Martinez 2009.

6. See, e.g., Peck and Ticknell 2002. This paradoxical but nevertheless widespread view conflates the totalizing force and pretensions of neoliberalism with the totality of human life, with the result that even critical appraisals end up "doing the work" of maintaining neoliberal hegemony by discounting practices and spaces that neoliberalism has failed to penetrate (Gibson-Graham 1996).

7. See, e.g., De Angelis 2001.

8. The territorial processes described in the previous chapter could be reread through this framework.

9. See, e.g., Tsing 2005; Scott 2009.

10. This could be read as an example of the pitfalls of environmental concerns framed by what Agnew $(1994,2010)$ terms the "territorial trap" based on three obsolete geographical assumptions: (1) states are fixed units of sovereign space that are (2) defined by the polarities of domestic versus foreign and internal order versus external anarchy, and (3) function as "containers" of societies organized according to a coherent set of interests.

11. National leadership now views regional environmental issues as commercial and security threats, and addressing them as serving broader political and economic objectives. Consequently, environmental concerns rose to prominence in international discourse in the last five years. The critique that state interventions in China's rare earth sector are driven by more than environmental concerns is valid; this does not negate, however, the severity of environmental and epidemiological harms resulting from rare earth mining and processing in Baotou and Bayan Obo.

12. These first three comprise the "three wastes" mentioned in Chinese scholarship.

13. Because its melting point is second only to tungsten and tantalum carbide, thorium is used in high pressure applications such as petroleum cracking, welding electrodes, carbon-arc lamps, and high temperature laboratory crucibles for melting refractory metals (Cardarelli 2008, 451).

14. Shortly after Marie Curie's breakthroughs at the turn of the twentieth century, drug and cosmetic manufacturers added thorium to everything from toothpaste to laxatives under the assumption that something so energetic as radioactive thorium had to be beneficial (O'Carroll 2011). The mania ended a few decades later following the grotesque deaths of prominent advocates of radioactive tonics (Rowland 1994).

15. For reasons of space, lead is omitted from this discussion. See Klinger (2015) for further reference.

16. Unlike other radioactive elements, radon is gaseous and easily inhaled. It is odorless, colorless, and tasteless. As such, it is generally responsible for the majority of public exposure to ionizing radiation (EPA 1990).

17. The Environmental Monitoring Station measured U-238, Ra-226, Th-232, and $\mathrm{K}-40$.

18. Village resident, male aged fifty-four, author interview, September 2013.

19. Village leader, male aged forty-six, author interview, September 2013.

20. Rural pastoralist, male aged sixty-one, author interview, September 2013.

21. Anonymous local official in Bayan Obo Mining District. Interview by author, September 2013.

\section{RUDE AWAKENINGS}

1. The KMT is pro-China and prointegration, so they are more likely to echo Beijing's utterances about the island. The Democratic Progressive Party is proindependence and tends to remain silent on the issue in the interest of maintaining smooth relations with what they view as their more developed neighbor (Kao 2014). 
2. Anonymous official in Port City A, interview by author, September 2013.

3. Anonymous port workers in Port City A, interviews by author, September 2013.

4. Newspapers as well as interviewees expressed conflicting dates; all fall between October 28 and November 24, 2010.

5. The Middle East has Oil, China has rare earths.

6. For more on this, see chapter 3.

7. For multiple analyses on the relationship between the raw materials WTO suits against China and industrial capacity in developed countries, see Meléndez-Ortiz, Bellmann, and Mendoza 2012; Blanchard and Wei 2013; Fratianni, Savona, and Kirton 2013; and Laïdi 2014.

8. As Chen (2011) has noted, the toxic hazards of production are racially and sexually coded within a global geopolitics of sovereign fear over foreign toxins hailing from distant production frontiers.

9. See, for example, Orris (2002) and Peters (2007).

10. US and international press reported US\$1 trillion in 2010; in 2011 and 2012 Afghan president Hamid Karzai claimed that the assets were worth US\$3 trillion. In a 2013 meeting with potential Indian investors, Karzai reportedly stated: “Actually it's \$30 trillion. The US knocked a zero off to keep our assets a secret” (Mehrotra 2013).

11. See, e.g., Abdullah, Chmyriov, and Dronov 1980.

12. Anonymous US-based economic geologist and mining consultant, interview by author, December 2014.

13. US federal rare earth researcher and lobbyist, interview by author, January 2014.

14. The Molybdenum Corporation of America, or Molycorp operated the mine at Mountain Pass from 1952 to 1977 when it was purchased by Unocal. It belonged to Unocal when it closed in 1999. Chevron acquired it in 2005 and sold the mine back to Molycorp in 2008.

15. These include various forms of tungsten, zinc, tin, niobium, tantalum, vanadium, antimony, phosphorus, pig iron, iron alloys, copper, copper alloys, nickel, and aluminum.

16. Bauxite, coke, fluorspar, magnesium, manganese, silicon carbide, silicon metal, yellow phosphorus, and zinc.

17. CBMM was established in 1955 following the discovery of niobium-bearing pyrochlore in Minas Gerais. Niobium is a soft, ductile metal used to make iron and steel super alloys, which are lighter, stronger, and require less base metal compared to other alloys. The niobium deposit mined in Araxá was formed by an alkaline magmatic intrusion referred to as chimney. These are carbonatite formations similar to those that formed the deposit at Bayan Obo, in which columns of magma pressed against the terrestrial crust in repeated cycles of heating and cooling over millions of years. They are essentially volcanoes that never quite happened. Just as the rare earth mine at Bayan Obo is rich in niobium, the niobium mine in Araxá is rich in rare earth elements. See Klinger 2015a.

18. CBMM's niobium-based technologies are used in nearly every jet engine, automobile body, hybrid fuel cell battery, suspension bridge, and superconductor produced in the last three decades; China, the largest producer and consumer of steel in the world, is entirely dependent on CBMM for its niobium supplies. See Klinger 2015b.

19. Anonymous personnel at CBMM in Brazil, interview by author, March 2014.

20. CBMM earned an ISO 14001 Environmental Management System Certification in 1997 and an OHSA 18001 Health and Safety Management System Certification in 2002.

21. Demonstrated by, among other things, the purchase of a 15 percent retainer of all of CBMM's known deposits in 2011 (Tudor 2011). 


\section{FROM THE HEARTLAND TO THE HEAD OF THE DOG}

1. This is a historically loaded term. "Brazil, Country of the Future" was a phrase coined in 1941 during the presidency of Getúlio Vargas to indicate the potential of the country to become a major world power. Since the end of the dictatorship in 1985, the phrase has been used sardonically to criticize the multiple failed national development campaigns. Rare earths, therefore, are presented as the vehicle to finally deliver the promise of Brazil's unfulfilled greatness.

2. CBMM has yet to publish price or production data for its rare earth products, and reportedly has not permitted major investors from Korea and China to conduct technical due diligence, due to the confidentiality surrounding its separation processes. This suggests that it was unable to produce rare earths at a price that could compete with Molycorp (2015), which reported losses of US\$67.2 million for 2013 and US\$99.6 million for 2014. Molycorp filed for bankruptcy in 2015.

3. As discussed in this chapter, categorical opposition to mining comes primarily from international advocacy groups and their cosmopolitan counterparts in Brazil.

4. Missionaries, soldiers, federal police officers on temporary assignment, rotating air traffic controllers, and Manaus-based traders, geologists, and politicians used this term. Local Indigenous people and other long-time residents did not.

5. A note on usage: Indigenous interlocutors referred to themselves as Indios, which translates as "Indian," and used this term interchangeably with povos indigenas, which translates as "Indigenous peoples." This chapter uses both terms.

6. Garimpeiros, or small-scale, artisanal, illegal, or clandestine miners, are much more visible in the Brazil case relative to the China case for two primary reasons. First, garimpeiros are politically organized and active in Brazil. Several garimpeiros I interviewed had cultivated allies in state and federal offices; interviewees in government office also referred me to garimpeiros because in their judgment, the garimpeiro perspective needed greater exposure. Second, and by contrast, small-scale or clandestine mining activity was subject to public condemnation and closure campaigns in China. Several officials interviewed in China expressed the sentiment that small-scale mining was irrational and evidence of backwardness. Furthermore, because Baotou and Bayan Obo are securitized areas, there was heightened sensitivity to speaking to foreigners. Even local officials actively supporting the clandestine mining activity stated that there was no possible way for a Westerner to speak to small-scale miners without consequences. Since the consequences would be most acutely felt by those in an already precarious position - the worst I would suffer would perhaps be interrogation and an order to leave-I judged it unethical to pursue this line of inquiry further in China.

7. This event was organized around my visit. A state geologist whom I had interviewed informed the commanding general of CMA that a gringa China expert was visiting the region. And furthermore, this gringa was not an anthropologist, which was taken to be a positive point by those typically criticized in anthropological enquiry in Amazonian regions. The general invited me to address CMA on the subject of rare earths and to offer my analysis on the environmental security impacts of mining as I had observed them in different parts of the world. Recorded with permission. All translations by author.

8. Fundação Nacional do Indio, the federal organ responsible for defending the rights and interests of Indigenous people.

9. The National Truth Commission determined that at least 8,350 Indigenous people were exterminated as a matter of state policy during the military dictatorship (1964-85), with an incalculably greater number affected, disappeared, or unaccounted for (Ricardo et al. 2014).

10. This exclusion of mineral extraction from "permitted" extractive activity is vividly illustrated in the Integrated Conservation and Development Projects in the Amazon in the 
1980s and 1990s. For a description of the failures of extractive reserves in the Amazon, which were intended to achieved conservation and development objectives through the sustainable extraction of nontimber forest products, see Dove 2006.

11. For an examination of the concept of the "ecologically noble savage," see Silva 2012.

12. Geraldo (retired garimpeiro), interview by author, April 2014.

13. To my knowledge, there is no rare earth separation in São Gabriel. It is carried out by downstream buyers in Manaus and Colombia. Local activity consists of extraction and transport.

14. Mr. Santos (Indigenous activist and local government staff, São Gabriel da Cachoeira), interview by author, April 2014. Mr. Santos is a pseudonym.

15. Geologist in Manaus, interview by author, April 2014.

16. FOIRN representative and founding member, interview by author, April 2014.

17. Mr. Domingos (FUNAI staff, São Gabriel da Cachoeira), interview by author, April 2014; FOIRN representative and founding member, interview by author, April 2014.

18. "A atividade visaria lucro, mas não do ponto de vista do mundo capitalista e sim no patamar da sustentabilidade, com uso de técnicas artesanais e concepções indígenas e levando em conta a relação com a natureza. Não queremos a presença de grandes empresas e grandes corporações fazendo o trabalho."

19. On the same days in which I was conducting interviews with Indigenous people in Cabeça do Cachorro, hearing heartfelt accounts such as Mr. Santos' as well as sophisticated legal arguments for the statutory protection for Indigenous mining operations on Indigenous lands, Davi was visiting San Francisco, California, to raise awareness and funds to pressure the Brazilian government to maintain the mining moratorium on Indigenous lands.

20. Mr. Domingos (FUNAI staff, São Gabriel da Cachoeira), interview by author, April 2014.

21. Three anonymous Indigenous veterans of land demarcation struggles, group interview by author, April 2014.

22. Located downstream from São Gabriel da Cachoeira toward Manaus.

23. However, there is no record of any such invasion and the original fort is now in ruins. In the Cabanagem rebellion of 1835-40, it was a political prison for captured rebels (Silva 2012), and during the Federalist Revolution in 1893 in the southernmost state of Rio Grande do Sul, the President Marechal Floriano Peixoto banished leading revolutionaries to Marabitanas (Oliveira 1968; Reis 1942). Because of the enduring concern among the Brazilian military that the Orinoco connection to the Caribbean Atlantic poses a national security threat (Brito 2013), it is now the site of the Fifth Rio Negro Frontier Command and the Fifth Special Border Platoon under the CMA.

24. Two US firms, the Chicle Development Company and the Rubber Development Corporation, established operations in São Gabriel da Cachoeira with the intention of taking over extensive rubber tapping networks to supply the US rubber market via the Rio Negro-Casiquiare-Orinoco waterway. Despite massive investment and resettlement programs, no amount of US public funds could overcome the deleterious effect of South American leaf blight that had driven rubber production to Southeast Asia decades ago, nor were they able to disrupt the established networks of local rubber barons. The extractivist initiative failed at an enormously high cost: in June 1945 an audit of the Brazilian office of the Rubber Development Corporation (RDC) found that costs exceeded income by US\$9.1 million during the war, while Brazil's Federal Congress estimated that between seventeen thousand and twenty thousand rubber tappers resettled to work in RDC's groves remained unaccounted for (Dean 1987, 104).

25. The final recommendations stated that "this report and maps be published and distributed to ... interested officials and agencies of the several participating governments, 
for their information and study [and that] copies of the report and maps be placed in the hands of all officials and agencies resident in and adjacent to the region, so that the maps and physical data may be available immediately to residents and students of the region" (US Army Corps of Engineers 1943, 297).

26. RADAM stands for Radar of the Amazon (Radar da Amazônia). It was later expanded to cover all of Brazilian territory and some of neighboring countries. The comprehensive survey is known as RADAM-BRASIL.

27. As characterized by Braudel 1967; Mumford 1934, 1967; and Merchant 1980, inter alia.

28. As characterized by Graulau 2003 and Lahiri-Dutt 2011.

29. Unless otherwise cited, the events described in the next three paragraphs are documented Wright's (2005) ethnographic account of the region, and were repeated to me by FOIRN leadership in 2014.

30. Mr. Domingos (FUNAI staff, São Gabriel da Cachoeira), interview by author, April 2014.

31. FUNAI had five presidents during that contentious year: Nelson Marabuto (September 1984-April 1985), Ayrton Carneiro de Almeida (April 1985), Gerson da Silva Alves (April 1985-September 1985), Álvaro Villas Boas (September 1985-November 1985), and Apoena Meirelles (November 1985-May 1986).

32. An expression akin to "play hot potato" or "pass the buck" in the sense that two or more parties attempt to buy time and avoid taking responsibility for an issue by claiming that responsibility lies with the other.

33. "I don't work with security. I support sovereignty through the construction of infrastructure. In the amazon there is no private sector to build the things that are needed. So we build them to help develop the region." PCN Director Brigadier Dantas, Ministry of Defense in Brasília, interview by author, March 2014.

34. Many of these were documented in the seven-thousand-page report submitted by public prosecutor Jader de Figuereido Correa in 1967. It is now in the possession of the National Truth Commission. At the time of this writing, it was not available to archival researchers.

35. It became formalized into a federal program in 1996.

36. At the time the US Drug Enforcement Agency documented much higher incidences of coca and marijuana plantations in Acre and just outside of Manaus. (Retired US intelligence official, interview by author, May 2014.) This makes sense for market and logistical reasons. Given this, it is unclear what was being "tested" in the upper reaches of the Rio Negro.

37. This is not surprising, given the reliance of FARC on supply shipments from São Gabriel da Cachoeira (Brasil 2003), the extensive economic ties between Indigenous groups on both sides of the border, and the sophisticated trading relations between Indigenous miners and cocaine producers seeking alternative routes for their goods. The relations are deeper than simply economic, however. Certain Indigenous groups maintain kin relations across the borders. Lack of health services in São Gabriel, aggravated by embezzlement of funds intended to provide services through the Ministry of Heath, provoked a healthrelated exodus of Indigenous people seeking medical care in Colombia. As part of the fight against FARC, the Colombian Ministry of Sanitation stopped delivering medical supplies and fuel to these frontier clinics in 2001 (Ricardo and Ricardo 2006).

38. With the 2016 Peace Agreement and the demobilization of FARC, it remains to be seen how ongoing militarization of the border will be justified.

39. Four firms supply the technology: Raytheon from the United States, MacDonald Dettwiler from Canada, and the Brazilian firms ATECH and Embraer (Perlo-Freeman 2004). The US Export-Import Bank provided 97 percent of the financing at 8.5 percent interest (Guzmán 2013; L. Martin n.d.). 
40. Created via Decree Law 12.836 of 1990.

41. Mining operations at Mountain Pass, for example, were built around rare earth concentrations between 2 percent and 3 percent (Olson et al. 1954).

42. US\$99.5 million to US\$295 million.

43. In 2003, the primary orientation of the Projeto Calha Norte shifted from sovereignty to developmentalism. The development axis now receives the majority of budget; in March 2014 the head of finances for PCN, Brigadier Dias, reported 1,800 separate development projects, including the construction of six universities in the neighboring province of Roraima. Although PCN does not have an explicit mandate related to natural resource extraction, "the best result of the program is the rapidity with which we are able to execute logistical projects because of our military approach. This will ensure the regularization of economic activity on our frontier."

44. "According to the Amazon Military Command, for two months in mid-2004 the FARC planned assaults on Brazilian Army positions along the 1,600-kilometer border between the two countries. The guerrilla group sought to obtain weapons, ammunition, food, and medical supplies. The military in Querari, a platoon on what was considered the most tense border was reinforced by forty men trained in jungle warfare. It was the last potentially aggressive movement of the guerrillas recorded by the Brazilian military intelligence network in the area of Brazil. At that time, satellite photos from the Ministry of Defense showed the marks of a camp through lower woods in an area customarily used by the guerrillas. Analysts of the Amazon Military Command in Manaus believe that the FARC was gathering a column with about 160 men and women in Jurupari" (Silva 2013, 31-32).

45. Commanding marshal Roberson of federal police post of São Gabriel da Cachoeira, interview by author, April 2014; Antonio, federal police officer, interview by author, April 2014

46. Antonio, federal police officer, interview by author, April 2014.

47. Brigadeiro Dantas, interview by author, March 2014.

\section{EXTRAGLOBAL EXTRACTION}

1. For example, astronaut Buzz Aldrin, award-winning science fiction author Ursula K. Le Guin, and planetary sciences professor John S. Lewis have written treatises contemplating lunar mining for very different ends.

2. $\mathrm{K}=$ potassium, $\mathrm{REE}=$ rare earth elements, and $\mathrm{P}=$ phosphorus.

3. Second only to orbital space, where satellites are located.

4. Anonymous NewSpace Industries investor, interview by author, August 2012.

5. The principle of the common heritage of all of humanity.

6. Those who take a more moderate position point to the article that vests the "appropriate state party to the treaty" with authority over nongovernmental entities in outer space in order to argue that it is up to national governments to determine which activities are permitted and which are not. The article in question reads: "The activities of nongovernmental entities in outer space, including the Moon and other celestial bodies, shall require authorization and continuing supervision by the appropriate State Party to the Treaty" (UN 1967, Article VI).

7. See, e.g., Grinde and Johansen 1995.

8. "The Moon Treaty was negotiated in the context of the North-South divide marked by the poverty of developing countries that had votes in the UN and the increasing power of multinational corporations to control economic resources. Space advocacy constituencies in the US saw the Moon Treaty as a power grab by poor developing countries to claim space resources through the power of UN bureaucracies that they did not have the technical means to reach on their own" (Beldavs 2013). 
9. Space mining entrepreneur, interview by author, November 2015

10. Vice president of space mining firm, interview by author, January 2014.

11. Russian venture capitalist Ilya Glubovich, for instance, reportedly began "chasing down" space startups in Russia in 2013, saying: "I want to give you money. Where are things right now?" (Bort 2014).

12. Global Business Development Manager for iSpace Technologies, lecture delivered at the University New South Wales, Sydney, Australia, November 6, 2015.

13. Planetary Resources intends to mine platinum group metals, principally on asteroids. Shackleton Energy Company plans to mine water and convert it into rocket fuel in the form of hydrogen and oxygen. This would essentially be a lunar gas station. Investor Richard Branson, of Virgin fame, reasons that if humanity is to explore the solar system, it needs to do so independently of Earth's resources. Although these initiatives are very important to the larger picture of the contemporary space race, they are nevertheless very different processes from the proposed rare earth mining on the moon and, as such, are not discussed in this chapter.

14. But first, they must land a rover and traverse a distance of five hundred meters, thereby claiming the Google Lunar XPrize, and then broadcast imagery back to earth in order to "prove the concept" that a company of fifty employees can successfully land on the moon. "Once we accomplish that, then the second or third mission can involve bringing things back from the moon" (Jain quoted in Caminiti 2014).

15. As Moon Express cofounder Bob Richards stated in the San Jose Mercury post: "The goal is to build out a transportation business that we think is profitable by itself for scientific and commercial payloads, but also to really start exploring the moon from an entrepreneurial perspective, which has never been done before.... It could be $\$ 15$ [billion] to $\$ 20$ billion of infrastructure you'd have to put in place to actually economically liberate that wealth," Richards said. "But those kinds of numbers, although big to a startup like us, are not big to existing mining concerns on Earth. Those are the prices of a typical mine, or even an offshore oil platform. If the resources are there, then the economics are there to liberate them" (quoted in Swift 2012).

16. This is an annual weeklong festival that began as a celebration of radical selfexpression and situationist art on Baker Beach in San Francisco in the 1980s and migrated to the Black Rock Desert of Nevada. The ten principles of the gathering are: radical inclusion, gifting, decommodification, radical self-reliance, radical self-expression, communal effort, civic responsibility, leaving no trace, participation, and immediacy (Burningman .org 2015).

17. Anonymous NewSpace Industries investor, interview by author, August 2012.

18. The perforated spheroidal shape described on the previous page was conceived in order to limit the amount of element lost to burn-off upon reentry through Earth's atmosphere to 7-10 percent.

19. See, e.g., Guner 2004.

20. Jointly developed by the Shanghai Aerospace System Engineering Institute and the Beijing Institute of Spacecraft System Engineering, the project began in 2002 and was completed in May 2010 (Xinhua 2008).

21. The array of entities developing China's space program are jointly overseen by CNSA and the state-owned enterprise China Aerospace Corporation, both of which are subordinate to the State Administration for Science, Technology, and Industry for National Defense. The State Council appoints its administrators. The Eighth National People's Congress was established it in its current form in 1993 in order to fulfill the country's mandate to cooperate internationally in scientific research and technological development. CNSA has active agreements with over a dozen countries and several multilateral space exploration organizations. 
22. See, e.g., Cheng 2011.

23. For an analysis of this amendment, see Kohler 2015.

24. "Peter Marquez, Vice President of Global Engagement, Planetary Resources, Inc., said, 'Our nation's continued leadership and prosperity in space is enabled by this new law. Planetary Resources is grateful for the leadership shown by Congress in crafting this legislation and for President Obama signing H.R. 2262 into law. We applaud the members of Congress who have led this effort. Marco Rubio (R-FL), Lamar Smith (R-TX), Patty Murray (D-WA), Kevin McCarthy (R-CA), Bill Posey (R-FL) and Derek Kilmer (D-WA) have been unwavering in their support and leadership for the growth of the U.S. economy into the Solar System" " (Planetary Resources 2015).

25 . This dynamic has been examined with respect to private defense contractors working in service of US military campaigns in Iraq and Afghanistan (Alexandra, Baker, and Caparini 2008; Gregory 2006; Menkhaus 2003).

\section{CONCLUSION}

1. Recall that state-owned enterprises, like other international firms, are driven by profitability concerns.

2. China Academy of Sciences Delegation to Brazil, interview by author, March 2013; China Academy of Sciences public health, ground water, and soil researchers, interview by author, August 2013.

3. What is less than 1 percent composed of? Primarily: rare earth scraps from magnet production, lamp phosphors, and nickel-metal hydride batteries.

4. Indeed, critical social theorists such as Mikhail Bakhtin (1968) and Henri Lefebvre (1991), among others, have rhapsodized the Carnival as containing the seeds for more promising alternative futures.

\section{APPENDIX}

1. In one instance in local archives in Inner Mongolia, this entailed the receptionist fabricating an entirely different set of requirements for me to satisfy once he saw that I had complied with all rules posted on the archive's website. These fabricated requirements involved getting letters of permission from a sub-office of a local bureau that-because these rules were made up on the spot-had no experience providing such a service. The put-upon officials in this particular local bureau made a phone call on my behalf, interrogated the receptionist as to why they directed a foreign researcher to their office, and resolved matters. 